\title{
Foot type biomechanics in diabetic and not diabetic subjects
}

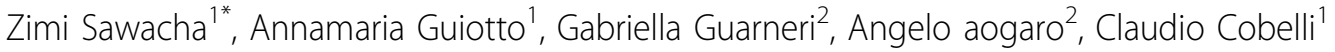 \\ From 3rd Congress of the International Foot and Ankle Biomechanics Community \\ Sydney, Australia. 11-13 April 2012
}

\section{Background}

The aim of this study was to investigate the role of foot morphology with respect to diabetes and peripheral neuropathy in altering foot kinematics, kinetics and plantar pressure (PP) during gait.

\section{Materials and methods}

Simultaneous 3-dimensional multisegment foot kinematics [1], kinetics and PP [2] of healthy and diabetic subjects with different type of foot were determined. 120 feet were examined (cavus, valgus heel and hallux

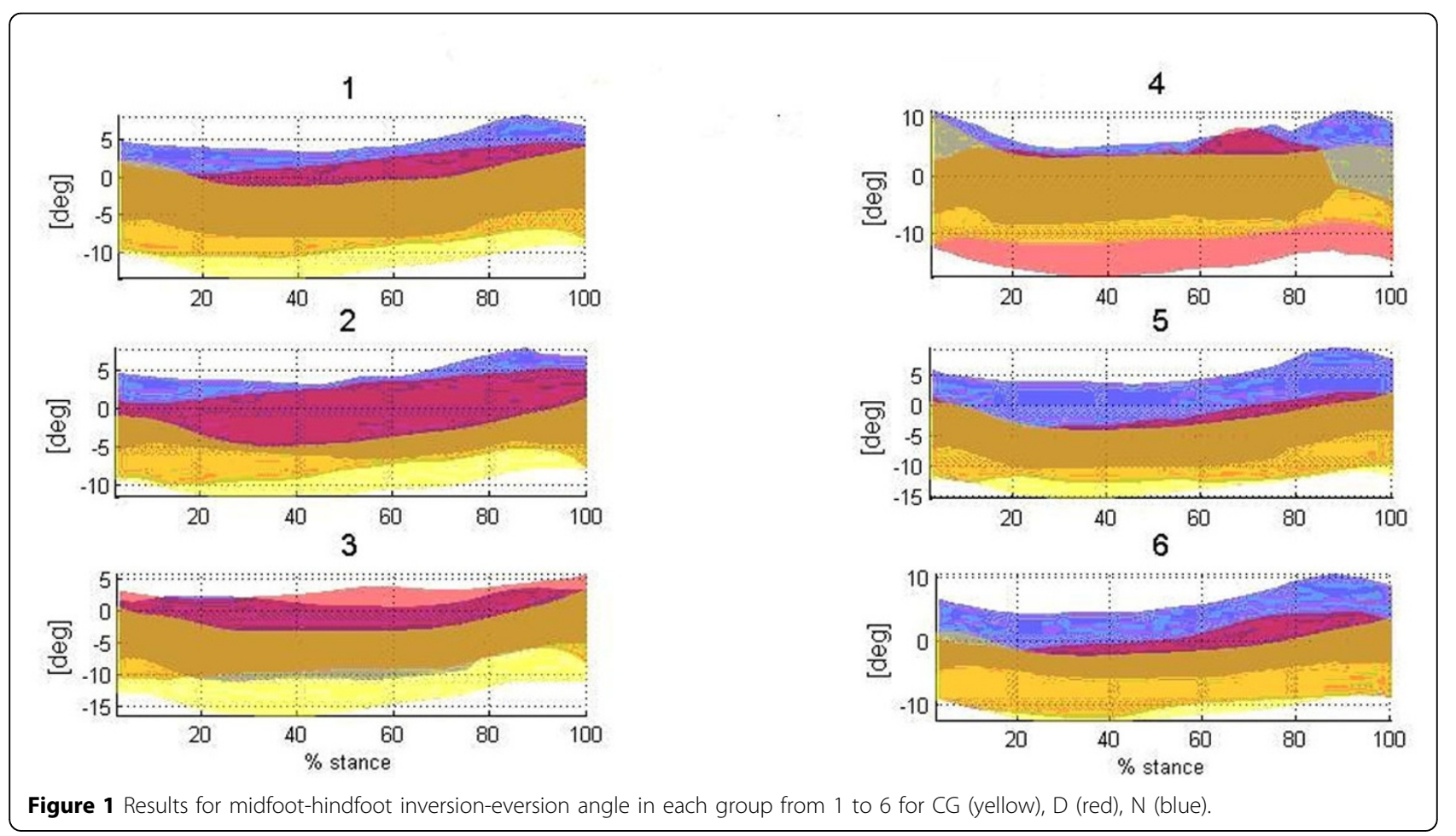

\footnotetext{
* Correspondence: zimi.sawacha@dei.unipd.it

1 Department of Information Engineering, University of Padova, Padova,

35100, Italy

Full list of author information is available at the end of the article
} 
valgus): 40 feet in the control group (CG), 80 feet respectively in the diabetic ((D) and in the neuropathic (N) groups. Furthermore, subjects were classified according to their foot morphology and each of the 3 groups was splitted in subgroups: 1 . cavus foot, 2. cavus foot and valgus heel, 3. cavus foot and hallux valgus, 4 . normal foot, 5. cavus foot and normally aligned heel, 6 . cavus foot and normal hallux).

\section{Results}

$\mathrm{D}$ and $\mathrm{N}$ subjects of groups 1,2 and 5 differed significantly $(p<0.05)$ from CG matched for foot morphology. Most of all D subjects in groups 1 and 2 were significantly more likely to display lower triplanar foot subsegments range of motion (especially in midfoot-forefoot dorsi-plantarflexion angle) and higher peak PP mainly in correspondence of the forefoot.

\section{Conclusions}

Results indicated the important role of foot morphology in altering the biomechanics of diabetic subjects.

\section{Author details}

'Department of Information Engineering, University of Padova, Padova, 35100, Italy. ${ }^{2}$ Department of Clinical Medicine and Metabolic Disease, University Polyclinic, Padova, 35136, Italy.

Published: 10 April 2012

\section{References}

1. Cavanagh PR, Simoneau GG, Ulbrecht JS: Ulceration, unsteadiness, and uncertainty, the biomechanical consequences of diabetes mellitus. J Biomech 2003, 26:23-40.

2. Sawacha $Z$, et al: Characterizing multisegment foot kinematics during gait in diabetic foot patients. J Neuroeng Rehab 2009, 6:37.

3. Giacomozzi $C$, et al: The role of shear stress in the etiology of diabetic neuropathic foot ulcers. J Foot Ankle Res 2008, 1:S1.

doi:10.1186/1757-1146-5-S1-013

Cite this article as: Sawacha et al:: Foot type biomechanics in diabetic and not diabetic subjects. Journal of Foot and Ankle Research 20125

(Suppl 1):013.

\section{Submit your next manuscript to BioMed Central} and take full advantage of:

- Convenient online submission

- Thorough peer review

- No space constraints or color figure charges

- Immediate publication on acceptance

- Inclusion in PubMed, CAS, Scopus and Google Scholar

- Research which is freely available for redistribution

Submit your manuscript at www.biomedcentral.com/submit 